\title{
Application of Science Media for Science Communication in Postgraduate Course to Elicit Emancipation
}

\author{
https://doi.org/10.3991/ijim.v15i23.27475
}

Nor Farahwahidah Abdul Rahman ${ }^{(凶)}$

Universiti Teknologi Malaysia, Johor, Malaysia

nfwahidah@utm.my

\begin{abstract}
This study reports on redesigning learning outcomes in terms of postgraduates' communication skills through science media communication with the aim for interactive teaching and learning. Communication in science education entails the image of science known as scientific epistemology. Therefore, the inclusion for learning about the philosophy of science among postgraduate students must not be limited to understanding the descriptive tenet of the philosophy. The initial work for this study attempts to assess whether learning about the philosophy of science dictates reflexivity and emancipation. Previous studies have not reached a consensus on how the impact of transformation can be created and recreated for others. Therefore, this study focuses on leveraging science media communication to foster conformity between oneself and others. Analysis was performed on ten postgraduate students' reports, writings, and portfolios obtained throughout the semesters. The analysis aims to critically discuss the proposed solution for the paradigm shift in teaching practice, with a specific focus on the course design outcomes. Using critical discourse analysis (CDA), the analysis identified liminal phases due to bearer as a professional among the respondents that habitually liberated through the five stages of transformation designed for this course. The following four liminal phases were interpreted from the students' reflexivity: identify negotiation, setup condition, a masking mechanism, and formation of oneself and others. Such points to the conclusion that placing students as the protagonist during the transformation process when learning the philosophy of science would expand their self-realization on the role of scientific epistemology in science education.
\end{abstract}

Keywords - agency, science media communication, science communication, philosophy of science, emancipation, self-reflexivity, design development research

\section{$1 \quad$ Introduction}

In this paper, I examine how learning the philosophy of science can benefit experienced students. Any discussion of the relationship between the role of technology and science educators communities in Malaysia begins with recognising ICT as the transformative agenda to improve the quality of education across the nation, as indicated in the National Education Blueprints 2013-2025 [1] [2]. Such a vision can be seen as a 
national movement towards empowering the teaching and learning process with greater accessibility to educational resources. Arguably, the movement has led to the massive implementation of technology-based teaching approaches among educators that focus on flexibility for greater accessibility.

Information and communication technology (ICT) is defined by the type of technology used in teaching. Its presence can be in the form of augmented reality, animation, or even as simple as a video presentation. In this paper, I argue the meaning held by ICT during knowledge construction as demanded by policymakers and practitioners. It is important to redefine the meaning of ICT to understand the kind of environment it provides for teachers' transformation. It is difficult to generalise the role of ICT because of the different philosophical traditions behind the use of ICT in education. However, all the traditions hold a similar understanding of 'integration'. A previous experimental study [3] employed GeoGebra as an integration between technology and mathematics content knowledge to facilitate students with the issues of visualisation. Others might probably use integration as a means for developing a resources hub akin to the measure adopted in another study [4]. While the call for integration is not new, leveraging science media for knowledge transformation is still worthy of discussion. This argument is based on the notion that the use of technology in STEM teaching (such as learning software, visualizations and modelling software, e-learning) could represent integration only as an intervention.

Developing content knowledge and knowledge construction are both leading STEM teaching in different arrays. In this study, I rather than focusing on designing and interpreting students' acceptance towards the role of philosophy of science. This paper follows the definition of 'systemic intervention' in [5][6], that systemic intervention is a purposeful action by an agent to create change about reflection upon boundaries. Hence, this paper seeks to answer the following questions:

1. What are the major decision points in the curriculum and instructional design when incorporating critical pedagogy for the philosophy of science course?

2. In what way the reflexivity and emancipation exhibit the transformative act among the postgraduate students to respond to changes?

\section{Literature review}

The concerns among Malaysian policymakers about STEM education can be traced to their argument regarding the 'supply' and 'demand' needed for national economic growth. Many studies have successfully identified the nature of the problem and its causes. The educational blueprints [1] summarises the following five major flaws in the STEM education:

i) Limited awareness about STEM

ii) STEM subject is difficult

iii) Content heavy curriculum

iv) Inconsistency of quality in teaching and learning

v) Limited and outdated infrastructure. 


\subsection{Agency in ICT for scientific knowledge development}

The present study sets out to examine how teachers are working with an educational system that requires them to respond to changes with the constraints stated above. Scholars in the past believed that technology can be resourceful to create meaningful classroom experience for science learners [7]. There is plenty of research that directly assesses the benefit of using ICT-based approaches as an initiative to teach STEM subjects. Such measures, however, are not the subject of interest for this study. Instead, the integration denotes a social limitation for the role of ICT in knowledge construction. My premise is that this is what differentiates between ICT as a tool and ICT as an agency. It is commonly held that when ICT is regarded as a tool, it is used to support the flexible learning environment. The support here remains primarily to ensure efficient delivery, better representation, increase participation, etc. For instance, when teaching about gas laws, students need to understand the nature of particles when certain variables are changing. Using simulation, the scenario is well represented by students as enrichment for their visualization.

Previous studies [8] [9] [10] have defined agency as the ability to exercise governance by developing and defining the outcome. Placed within this perspective, the position carried by the technology in teaching and learning can be said to have a capacity to determine the mechanism for the process of scientific knowledge construction. When teachers design their course of action using technology, they begin to adjust the epistemic entities in a STEM subject as reflective responses to the social structure. Such a measure is akin to revising how STEM knowledge must be taught at school. Therefore, the technology agency can be conceptualized as the capacity of the technology to culturally reproduce and transform scientific practice.

The philosophical critique above does not condemn nor object to the role of technology. Instead, the liberalization made in experimental studies among Malaysian teachers and scholars involving technology invited me to adopt technology advantages and leverage it as a learning outcome. One study [7] discussed this matter and separated the practice as technological content knowledge (TCK) or technological pedagogical knowledge (TPK). TCK is when technology is used for enrichment in representing the content knowledge. On the other hand, TPK surfaces when teachers have an understanding of the pedagogical nature of technology. Although TPCK has been defined using Shulman's PCK as representing 'a class of knowledge that is central to teachers' work with technology' [7][11], its theoretical perspective only holds true for making the integration visible. In this article, I does not entirely subscribe to either TPK, TCK, or TPCK. Rather, I move the focus from what technology may benefit the education to what is an education focusing on technology supposed to achieve?

I am fully aware that the individualistic view plays its role in teachers' decisions on what kind of technology they are comfortable with when transforming a lesson. The potential for changes is expanded in this study by looking at the transformation of oneself and others [12]. It is important to highlight oneself and its capacity as a learning outcome for postgraduate students because the majority of them are teachers learning to be a practitioner of education. Since epistemological questions become clearer for leveraging ICT for knowledge construction for this, means and strategies to achieve the desired outcome invite science media into the discussion. Science media literacy focus 
on creation and communication [13] and the epistemic foundation is used as strategic discourse to harness the transformation.

\section{Methods}

This study involved postgraduate students who enrolled for the Philosophical Issues in Science, Mathematics, and Technology course. This course is offered as an open elective in Master of Education (Physics, Chemistry, and Mathematics) programme. The course aims to introduce students to the ontology and epistemology commitment as STEM educators. The first author in this study is the instructor and curriculum developer for this course since 2017. This study relies mostly on an explanatory research design following Tyler's Curriculum Model for the design phase. A basic curriculum design principle consists of the objectives, content, learning experiences, and evaluation [14]. The focus of this study is to analyse the proposed critical pedagogy in the curriculum design. However, the paper discusses only the implementation and evaluation phase from the instructional design stages as part of the actual work, which employed designbased research as a methodology. The data collection and analysis were carried out qualitatively from ten students' portfolios in the span of three semesters, using critical discourse analysis (CDA).

\subsection{Context of the study}

The attention of this study is directed to the course learning outcome intended for communication skills. The course learning outcomes for communication skills were redesigned and revisited using the critical social theory and critical pedagogy [15] conceptions of teaching, learning, and curriculum. The revised version of the course learning outcomes (CLO) for communication skills is 'to reproduce multiple ways of crafting thinking in classroom visually using the underpinning philosophy for teaching'. The data were collected for two semesters from 2019 until 2020. In both semesters, the percentages of competence for communication gained were 67 and $71 \%$, respectively.

I drew on agenda-setting, priming, and framing to transform teachers' prior worldview on communicating science through social media during the curriculum design. The critical pedagogy does not have a specific model but outlines the nature of educational outcomes that persisted among the students. The instructional design of this course formed the empirical context for the study reported here.

The written reports were collected for three semesters, involving ten postgraduate students. As STEM teachers, they needed to understand the role of philosophy of science and how to position the philosophy as a game-changer in their practice by Week 4 of the semester, particularly after analyzing the teachers' talk. Table 1 describes the course of how the students were guided to experience self-reflexivity and emancipation. In the following weeks, the students present the analysis to understand particular problems related to existing practices, using science media as a tool to guide the process. Throughout the semesters, they engaged in reflective discussions to identify any obstacle to solving the problem and how enacting acting on the problem may lead to 
different outcomes. The limitation was further outlined to relate to the instructional approach. The course ended with a video presentation exemplifying the teaching transformation by communicating philosophy application in teaching. The students were invited to play a role as a specialized curriculum designer by envisioning what constitutes effective science communication.

Table 1. Course design inquiry restructured using critical theory and critical pedagogy

\begin{tabular}{|c|c|c|}
\hline $\begin{array}{c}\text { Stages for Reflexivity and } \\
\text { Emancipation }\end{array}$ & Instructions Given to Students & $\begin{array}{l}\text { Weeks (14 Weeks } \\
\text { for a Semester) }\end{array}$ \\
\hline $\begin{array}{l}\text { Identify particular issues in } \\
\text { their philosophical aspects of } \\
\text { existing science discourse }\end{array}$ & $\begin{array}{l}\text { Reflection on who we are, what } \\
\text { we have, what we want to go, } \\
\text { why we want to go }\end{array}$ & Week 1-2 \\
\hline $\begin{array}{l}\text { Identify the philosophical } \\
\text { problem with teaching } \\
\text { practices and discourse }\end{array}$ & $\begin{array}{l}\text { Critical analysis of the habit of } \\
\text { mind and chosen curriculum } \\
\text { approaches }\end{array}$ & Week 3-4 \\
\hline $\begin{array}{l}\text { Identify the role of the } \\
\text { problem and limitation } \\
\text { created by the problem }\end{array}$ & $\begin{array}{l}\text { Gathering resources, creating } \\
\text { ideas, and constructing new } \\
\text { meaning }\end{array}$ & Week 5-7 \\
\hline $\begin{array}{l}\text { Identify a possible solution } \\
\text { for the problem to be solved }\end{array}$ & $\begin{array}{l}\text { Integration of newly constructed } \\
\text { knowledge }\end{array}$ & $\begin{array}{l}\text { Week 9-10 (*semester } \\
\text { break in Week } 8)\end{array}$ \\
\hline $\begin{array}{l}\text { Identify the possible function } \\
\text { of science media for the } \\
\text { problem to be solved }\end{array}$ & $\begin{array}{l}\text { Carrying out reconstructed } \\
\text { knowledge through science } \\
\text { media approach }\end{array}$ & Week 11-13 \\
\hline $\begin{array}{l}\text { Identify possible ways to } \\
\text { pass the obstacles curriculum }\end{array}$ & $\begin{array}{l}\text { Reflection on the impact created } \\
\text { by the video on personal } \\
\text { development as teachers }\end{array}$ & Week 14 \\
\hline
\end{tabular}

\section{$4 \quad$ Findings}

As an instructor myself, it has been challenging to teach philosophy to nonbelievers because students often do not see the leverage for learning philosophy as a teacher. I define this situation as a nonobvious gap in teaching practice which students failed to recognize in themselves. My interpretations when reading the reports were extended to understand how learning about science media facilitates the students' reconceptualization of teaching practices based on the philosophy.

This paper describes partly the outcomes from a design-based research that aims at developing curriculum and instructional design using critical pedagogy as the design principal. When it was implemented, data were collected to further analyzed the extent of changes in the proposed design to students' emancipation and self-reflexivity. Data were collected from students' report writing throughout the semesters. The purpose of the course's inquiry was to guide students to unpack their philosophy and translate their understanding into the media of communication. They were required to measure changes in their ability to analyze philosophical stances from video recording lessons that were recorded by themselves. The videos portrayed their normal scientific discourse. 
The analysis led me to discover the students' liminal period in which their reflexivity and emancipation were both limiting and enhancing the paradigm shift. The concept of liminality came from the Latin word linen, which means a context of boundary [16]. The battle for this course to influencing, persuading, and commanding students for a paradigm shift occurs during science media communication tasks. The science media is the solution that students must propose to a larger audience to help them understand the role of philosophy in STEM teaching. The students were introduced to the concept of agenda-setting, priming, and framing as the detrimental sources of control for the paradigm shift. The formulation of the science media as a reflective and emancipate tool was adopted from a previous study [17]. Each element that the students must consider when communicating their ideas through video is summarized as follows:

1. Agenda Setting - raising noticeable issues on teaching practices using philosophical as the basis

2. Priming - activating philosophical assumption among audience related to common practice in teaching STEM

3. Framing - choose how they should frame issues related to philosophy in teaching to persuade the audience of the content delivered

Communication skill is the desired technical learning outcome of the course, which is often conducted as a slide presentation. The traditional way focuses more on evaluating communication skills but not on leveraging communication as the source of reflexivity and emancipation. I chose science media as it would allow students to unfold their understanding as they attempt to communicate the application of philosophy in teaching practices to a larger audience. Thus, here, the application of technology is not limited to a tool; the video developed aimed to deconstruct the symbolic understanding attached to an existing understanding about philosophy. Along with the process of developing reflexivity and emancipation for changes, the activities using science media were intended to overcome subjugation and immaturity the students initially held in their practice.

The philosophical thinking formation was analyzed in every stage of learning designed for this course. The liminal phases were later identified for issues that the students encountered and how the liminal was enacted by them. The findings are summarized in Table 2 below. The analysis is preliminary work done to develop a liminal identity for the students to become practitioners. The finding shows that four liminal phases were encountered by the students as they tried to navigate the paradigm shift and communicate their emancipation. 
Table 2. Summary of findings from critical discourse analysis (CDA)

\begin{tabular}{|c|c|c|}
\hline $\begin{array}{l}\text { Stages for Reflexivity and } \\
\text { Emancipation }\end{array}$ & Liminal Phase & $\begin{array}{c}\text { Contextual Cues Identified from } \\
\text { Reflexivity }\end{array}$ \\
\hline $\begin{array}{l}\text { Who am I and what I have } \\
\text { been doing? }\end{array}$ & \multirow[t]{2}{*}{$\begin{array}{l}\text { Identity negotiation } \\
\text { channel from } \\
\text { existing practices }\end{array}$} & $\begin{array}{l}\text { Self-doubt and self-realization from } \\
\text { everyday thinking. Students begin to create } \\
\text { meaning for every decision they made, and } \\
\text { if this meaning is resourceful for them }\end{array}$ \\
\hline $\begin{array}{l}\text { Identify particular issues in } \\
\text { existing science discourse }\end{array}$ & & $\begin{array}{l}\text { Safety valves that students keep on } \\
\text { negotiating for its meaning but create the } \\
\text { condition that firm up the domination }\end{array}$ \\
\hline $\begin{array}{l}\text { Identify the philosophical } \\
\text { problem with teaching } \\
\text { practices and discourse }\end{array}$ & $\begin{array}{l}\text { Setup condition } \\
\text { for existing } \\
\text { philosophical stance }\end{array}$ & $\begin{array}{l}\text { Conditions created for antimony or the } \\
\text { feeling of in-betweenness that they felt } \\
\text { toward themselves, students, and school. }\end{array}$ \\
\hline $\begin{array}{l}\text { Identify the role of the } \\
\text { problem and limitation } \\
\text { created by the problem }\end{array}$ & $\begin{array}{l}\text { Masking } \\
\text { mechanism }\end{array}$ & \multirow[t]{2}{*}{$\begin{array}{l}\text { Hopes that students put forward for } \\
\text { teaching practice and insignificant } \\
\text { resistance that suspend the wills }\end{array}$} \\
\hline $\begin{array}{l}\text { Identify a possible solution } \\
\text { for the problem to be solved }\end{array}$ & \multirow[t]{2}{*}{ Oneself and other } & \\
\hline $\begin{array}{l}\text { Identify the possible } \\
\text { function of science media } \\
\text { for the problem to be solved }\end{array}$ & & $\begin{array}{l}\text { Recognize the purpose of conducting } \\
\text { reflexivity to continuously learn about } \\
\text { themselves }\end{array}$ \\
\hline
\end{tabular}

\subsection{Identity negotiation channel from existing practices}

In this phase of liminality, I explored the students' reflexivity beginning from the introduction to the philosophy and after they carried out text analysis on discourse. During this period, the students described their experiences as confusing and embracing the new ways of knowing. The activities served to ensure that the students were performing their habitual paradigm when enacting the practices. For instance, the liminality concern for Marini, who has 35 years of experience in teaching, was on the pessimistic view she had when learning about philosophy against her personal view. The early experience in this course is not always as bright as Marini's; Manghes, on the other hand, fell too deep into confusion. He tried to give conformity to his personal views, led by his moral views to learn philosophy as a science teacher. On this account, the excerpts exhibit the capability of cognition among the students to learn about philosophy:

Marini: Through all my 35 years of teaching, it has never crossed my mind that there is a specific field of study on how people think and develop knowledge. In my mind, there was only 'I know that' or 'I don't know that'.

Manghes: Sometimes it appears as if I am walking through a pool of darkness with no direction of where I am going. But along the line, when I subject my cognition to deep thinking, then I would understand some points involved. At some point, I felt like dropping the course, but I remember how important knowledge of philosophy is to an educationist. Philosophy is used in daily activities such as communication with one another in the same or different languages. 


\subsection{Setup condition for existing philosophical stance}

The setup condition recognized that the mingle around the students' laminal phase was due to the bearer as professionals. At the beginning of the semester, they displayed an awareness about new knowledge gained from this course and discussed this awareness during class activities. The bearer targeted their existing practice, which immediately led them to recognize themselves as novice despite their years of experience in teaching. The in-between feeling of knowing and not knowing what they have been doing is visible during these stages. The bearer becomes the condition in which I maintain to students in the following stages by providing a basis to appropriately believing that existing practices require a thorough inspection.

During this liminal phase, I have encountered a different type of reflexivity among students that show common ways of conceiving emancipation for their practices. Like in Figure 2, the key for Asha to understand her role as a teacher is through actively engage to provide a counternarrative for her discourse. This affirmation that she frequently refers to in the following activity as teacher-centered also presents evidence that she is able to recognize the type of condition that leads to this nature of the conversation.

I found my communication with student as rather rhetoric. I persuade my student to just accept what I gave her. I leave her little space to argue with me. My communication with student is rather far from inquiry based learning. I did throw questions at her but the main purpose could be seen as to get a 'yes' or 'no' from her. Or to just leisurely checking on her by casual talk. For an example:

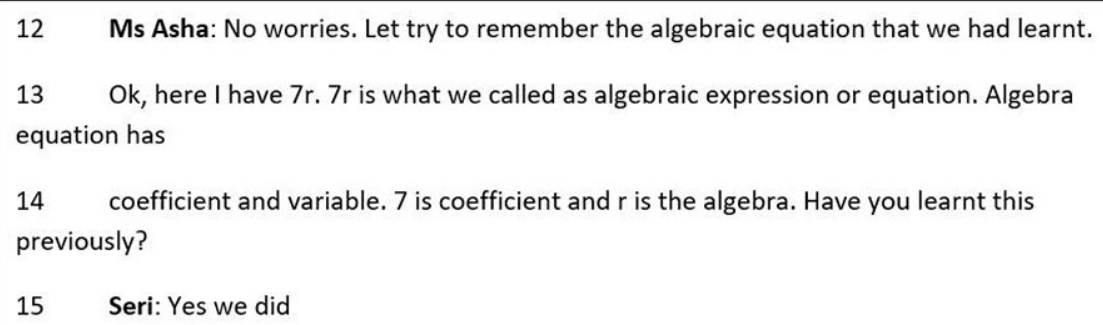

Fig. 1. Asha's reflexivity accounts after analyzing her classroom talks

Asha, an experienced private tutor, highlighted the issue of the relationship between her contribution and the knowledge proposed in school. From the start, she admitted that her approach is characterized by the didactic approach, which places herself at the center of knowledge development. Asha maintained that she has been doing fine with the teacher-centered approach and that her emancipation can be easily understood as ignorant. However, the importance of Asha's counter-narrative to the activities lies in the fact that she can detect and criticize her practice:

Asha: My nature as a tutor where I supposed to aid's student lack of understanding that they developed from school influence me to react that way. I have the tendency to make sure students get the facts right according to the book. I look 
at my scope of work as a form of factual supplement to these students and let the school address their skill and affective development. Nevertheless, $\underline{I \mathrm{am}}$ pretty sure there is a way I can continue to become the school's supplement while preparing these students to build the $4 C$, (collaborate, critical thinking, communication, and creativity) by balancing my teacher-centered classroom with students active engagement.

\subsection{Masking mechanism}

Taken together as the bearer for this stage, the students were guided through activities like examining classroom talks, conducting a comparative analysis of classroom practice, and individual reflexivity. The substance of the inquiries focused on assessing whether the bearer as a professional helps the students to regain a capacity that belongs to the problem of masking. Masking is an act of eliminating differences made by practices that display automatically with the presence of goals. Thus, modifying the goals in teaching became the contextual cues to the students, which automatically triggered the desired reflexivity and emancipation. For instance, instead of having scientific literacy, the desire goals were directed to enacting scientific literacy. The students carefully developed causal hypotheses in each class activity so that the action that was activated happened due to exposure to those contextual cues.

The excerpt below comes from Chitra, an experienced primary science and mathematics teacher. She put herself in between two major paradigms that act as her linguistic marker to relate to her own decision in teaching. I initially designed this stage for students to begin to reconstruct their identity as science teachers. However, masking their ways of relating to their experience and justification does not consolidate with the conditions prepared for their emancipation. Thus, I began to provide students with a comparative analysis of micro, macro, and symbolic representation of the quality of science knowledge delivered during the talks. Chitra's case is not unique as I encountered other students with antinomies too. I struggled a lot during this phase, moderating the discussion using their antinomies to frame emancipation:

Chitra: As positivist and constructivist are known as opposite wings of philosophy as positivist believes that knowledge is generated using scientific method and constructivist believed that knowledge is generated by the scientist. I personally believe that a person can have two perspectives. As a teacher, I would like to think of myself to look in the shoes of both my students and myself. Yes. I do believe that knowledge is being generated using the scientific method, but at the same time; I do believe that the scientific method will never exist without scientists. So, being the opposite thinker has its perks, as, we are able to see in a wider scope for the betterment of my students.

Here is an example is taken from Chitra's work in which she was required to move the existing ways of talking that focus on social reproduction to social transformation. The activity targeted creating a dialog with herself and her friends on categorizing the talk into social reproduction and social transformation. Chitra reached an understanding of how her existing philosophy would dispossess students' will. Underpinning the 
antinomies here is a simplification that students want to provide when teaching concepts that are relatively known for abstraction. The activities following this are designed to intellectually challenge the oppressive social structure created when teachers are maintaining antinomies. As in Figure 3, students need to find hope in their existing inquiry that can be beneficial to their audience.

Task 8: Social Transformation and Social Reproduction

\begin{tabular}{|l|l|}
\hline \multicolumn{1}{|c|}{ SOCIAL TRANSFORMATION } & \multicolumn{1}{c|}{ SOCIAL RE-PRODUCTION } \\
\hline Make changes in thinking & \multicolumn{1}{c|}{$\begin{array}{c}\text { Focus on learning without changes in } 5 \\
\text { pillars. }\end{array}$} \\
\hline T: What is the importance of coordinates? & $\begin{array}{l}\text { T: Try to find the coordinates of the object } \\
\text { given }\end{array}$ \\
\hline T: How to find the tables of values? & $\begin{array}{l}\text { T: What shape do you think the graph is } \\
\text { going to be? }\end{array}$ \\
\hline T: Is linear graph always straight line? & \\
\hline
\end{tabular}

Fig. 2. An example of further conditioning provided in this stage

\subsection{Domination of science media for changes}

Toward the end of the semester, the students were given a final task requiring them to enact the philosophy to a larger audience using science media as a tool for communication. The end task of the communication skill was to develop a video about philosophy on YouTube. The science media task required the students to use the same contextual to communicate the idea using video, as shown in Figure 3. 
A video presentation is produced to explain the audience about reconstruction lesson plan. This phase is to educate the people about paradigm shift experienced and the way to do it systematically. This video presentation can be watched at https://drive.google.com/file/d/1KzGdQBk6vPagZElhW1H2Cju4p 0sMOQZ/view?usp=sharing.

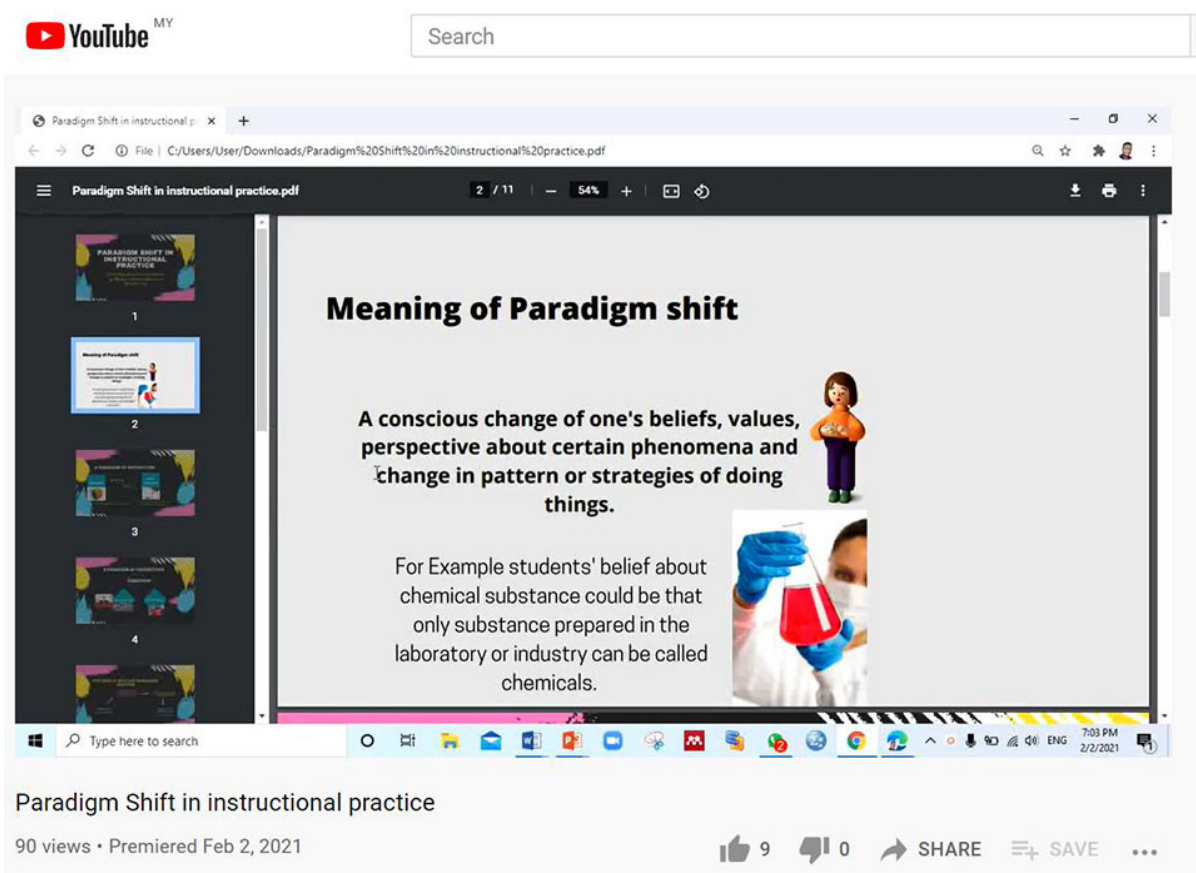

Fig. 3. An example of video developed by student and it's report

The way students navigate between different ways of expressing their identity is motivated by what they perceived as the right way to do it. Regarding the students in this study, although their vision for emancipation was subjected to criticism throughout the semester, they were able to recognize the reasons used to sustain domination within an existing practice. The excerpts are the examples taken from the students' responses on their transformation to communicate philosophy visually to a larger audience using a video. Shukurniah, a physics teacher at a private school, has been learning to teach informally. She described her whole experience as liberating from her current view about understanding how people think:

Shukurniah: I start to think that this course may help me to understand how my students think. It is so difficult to identify what people are thinking about things. In my point of view, having knowledge about how students think contributes to the ways how knowledge has been constructed. 
Some students rejected the emancipation and this can be traced to their insignificant acts of resistance. Therefore, I focused their struggle to emancipate and found that among the factors leading to it was over-reliance on what works for them.

\section{Discussion}

Although this paper does not empirically look into the connection, conceptually it explains what happened during the period of learning philosophy. The discussion aims at providing explanations related to decision-making made during implementation and indicators found from the analysis as new theoretical constructs in critical pedagogy. The evaluation identified the development requirements that I need to reconsider when implementing the proposed curriculum and instructional design. These findings explain the requirements (known as laminal phases) which connect the curriculum and instructional design being developed with the problem that drove the development.

There are a growing body of evidence indicating how ICT interplays with the current teaching practice and supports learning. It is imperative that the researchers in this era study the effect of specific ICT instructional strategies. The major implications of these studies have generated empirical evidence supporting the effectiveness of using ICT as an instructional strategy in STEM lessons. Therefore, the integration of ICT in education is desirable among educators and often regarded as empowerment. Such a notion explains why ICT has been mentioned in various education policies, such as the Malaysia Educational Blueprint 2013-2025. In this policy, ICT is positioned as the transformative tool that can facilitate the initiative reaching for quality education. In this study, I acknowledge that the predetermined learning outcomes for STEM learning have become the pre-existing structural functions for transformation, as reported in [18]. Coming back to the aims of this study, connecting science media to reflexivity and emancipation was done initially through the causal hypothesis, which enacted that the philosophy of science can be done through taking action with philosophy.

My biggest challenge as a course owner for the postgraduate course is to provide a satisfying experience since postgraduate students all have pre-condition to existing practices in teaching. From the findings, it is important to note that providing space to enact transformation is a reconstructive process. Designing the course according to the critical theory and critical pedagogy has helped me to reshape the identity that students must acquire from the learning outcomes for communication skills. Instead of placing communication procedurally, communication is continually assessed as emancipation knowledge. My work is advocated with the movement that requires educationists to enact changes in educational reform. I explored the pedagogical production proposed for this course by drawing on how science media helps to guide reflexivity and emancipation. Since this is only preliminary work, the analysis only shows how each stage prepares teachers to enact with the liminal phases.

The reconstruction stage has a wider horizon for the liminal phase from identifying setup conditions and masking mechanisms. Regarding identity formation, the liminal phases were found to reduce the students' engagement with the existing views by building reliance on how their actions are controlled by discourse and practices. This pathway served as an antidote for the students to deconstruct and reconstruct self-identity 
as STEM teachers. One highly cited work [19] discusses colonizing pedagogy and proposes that teachers learn through tracing a pedagogical pathway. Similarly in this study, the tracing process exemplified by deconstruction and reconstruction became a push factor for the teachers in this course to create a window of opportunity for changes. The students were guided to scrutinize why they teach certain ways and not others. Their prior philosophy of science was developed in response to the positivist paradigm, which views science largely as the descriptive knowledge of the existing phenomenon. In this sense, the use of agenda-setting, priming, and framing from science media [6] as a communication tool helps with the scrutinizing process. The teachers learned to select issues relevant to them, shape the way how the issues were brought to their practice and begin to characterize scientific knowledge following these when communicating science to a larger audience. Supplementing the students with this tool was expanded to help them recognize the cognitive effect due to the epistemic problems in communicating scientific ideas.

The students indeed faced difficulty, which they referred to as exaggerated cognitive load when masking their epistemic commitment. Learning from their experience for the paradigm shift showed that the causal hypothesis linking intervention and outcomes is sufficient to serve as a basis for appropriately believing that communication can be designed as emancipatory knowledge for students. The students were able to identify the determining influence of their prior practice and learn to negotiate this meaning during the final stage. Finally, they were assessed for communicative competence by looking at how far they have reached in meaning negotiation with themselves and others. At that stage, they were assessed for their communicative competence in negotiating meaning and purposes.

When analyzing the learning sequence design for this course, I learned a lot about assisting transformation from students' liminal phases. The tenor of students' reflexivity helps them to exercise emancipation. During a presentation, students may choose between agenda-setting, priming, or setting to select ideas and negotiate meaning with the audience. This is when emancipation becomes visible to their choice of rhetoric. As an instructor, my biggest fear is students' inability to adapt to the reconstruction process and consequently their being drowned for the whole semester. Although their choice of presentation varied and they showed maturity engagement in the whole inquiry process, some students maintained the initial paradigm in teaching for its convenience. This is because the emancipation targeted in this course is limited to a social determination as to the source for emancipation.

I did not see the endeavor as a failure to the case proposal in this study. Instead, the students exhibit that when reflexivity is not subject to social determination, one is represented as antinomies. The benefit of education from emancipation practices is not persuasive because it leads to autonomous students, meaning an increased variability of learning outcomes for science. Thus, maintaining the existing view by continuously being aware of the limitation presence is more comforting. Having this view in their act of teaching science showed a case in which teachers may engulf themselves in discourse that does not belong to them. The reconstruction, which was not built on a liminal phase, shows teachers who unknowingly restrict themselves from responding to changes. These teachers have seen teaching as producing knowing and not becoming. This is how the limitation to the findings was identified; the data do not inform the 
analysis whether the teachers were exhibiting such a view. Yet, certainly, the teachers limited their emancipation, as they relies mostly upon collective movement in teaching.

\section{Conclusion}

This project concludes that nailing the students to the reams of scepticism exemplified how reflexivity and emancipation can be delivered in a course design. The endeavour has demonstrated how science media has been particularly useful for students to challenge the dominant views held by them. Although the CDA analysis presented in this study has its limitation to present the impact as causal, the accumulation of reflexivity activities showed how critical pedagogy can be useful as social innovation to educationists. The conditions created by the pedagogy would allow students to actively revisit their decision, attitude, understanding, and action in teaching and learning. Despite the evidence indicating that not all emancipation can be activated the approach allows one to peek at the central aspect of understanding educationist ideology structured and shaped in a centralized education system. Further study is needed to look into daily emancipation in close inspection and how this can be incorporated into the inquiry design in a postgraduate course. With this direction, I hope future studies allow the opportunity to assist postgraduate students with individualized forms of resistance.

\section{$7 \quad$ Acknowledgement}

This project is funded under Fundamental Research Grant Scheme (FRGS) FRGS/1/2018/SSI09/UTM/02/5 by The Ministry of Education Malaysia with vote number R.J130000.7853.5f067.

\section{References}

[1] Blueprint, M. E. (2017). Blueprint 2013-2025. Ministry of Education.

[2] Ngah, A. B., \& Songip, A. R. (2016). Open Innovation Approach in the Development of Malaysia Higher Education Blueprint. Innovation and Management, 1491.

[3] Dockendorff, M., \& Solar, H. (2018). ICT integration in mathematics initial teacher training and its impact on visualization: the case of GeoGebra. International Journal of Mathematical Education in Science and Technology, 49(1), 66-84. https://doi.org/10.1080/00207 $\underline{39 X .2017 .1341060}$

[4] Valenzuela, B. D., Fragoso, O. G., Santaolaya, R., \& Munoz, J. (2017). Educational resources as learning Web services, an alternative point of view to learning objects. IEEE Latin America Transactions, 15(4), 711-719. https://doi.org/10.1109/TLA.2017.7896399

[5] Midgley, G. (2000). Systemic intervention. In Systemic intervention (pp. 113-133). Springer, Boston, MA. https://doi.org/10.1007/978-1-4615-4201-8 6

[6] Rajagopalan, R., \& Midgley, G. (2015). Knowing differently in systemic intervention. Systems Research and Behavioral Science, 32(5), 546-561. https://doi.org/10.1002/sres.2352 
[7] Eady, M., \& Lockyer, L. (2013). Tools for learning: Technology and teaching. Learning to teach in the primary school, 71

[8] Archer, M. (1998). Realism and Morphogenesis. In Archer, M., Bhaskar, R., Collier,

[9] Archer, M. (2000). Being Human: The Problem of Agency. Cambridge: Cambridge. https:// doi.org/10.1017/CBO9780511488733

[10] Rahman, N. F. A., Roslan, A. N., Azaha, A. N., Ismail, N. H., \& Murshed, M. (2021). Informal Science Pedagogical Innovation to Promote Understanding of Technology Application in Fluids Mechanics. International Journal of Emerging Technologies in Learning, 16(18). https://doi.org/10.3991/ijet.v16i18.25083

[11] Koehler, M. J., \& Mishra, P. (2014). Introducing TPCK. In Handbook of technological pedagogical content knowledge (TPCK) for educators (pp. 13-40). Routledge.

[12] Wolff, L. A., Sjöblom, P., Hofman-Bergholm, M., \& Palmberg, I. (2017). High performance education fails in sustainability? A reflection on Finnish primary teacher education. Education sciences, 7(1), 32. https://doi.org/10.3390/educsci7010032

[13] Höttecke, D., \& Allchin, D. (2020). Reconceptualizing nature of science education in the age of social media. Science Education, 104(4), 641-666. https://doi.org/10.1002/sce.21575

[14] Hunkins, F. P., \& Ornstein, A. C. (2016). Curriculum: Foundations, principles, and issues. Pearson Education.

[15] Freire, P. (2005). Pedagogy of the Oppressed. New York: The Continuum International Publishing Group Inc.

[16] Rantatalo, O., \& Lindberg, O. (2018). Liminal practice and reflection in professional education: police education and medical education. Studies in Continuing Education, 40(3), 351-366. https://doi.org/10.1080/0158037X.2018.1447918

[17] Scheufele, D. A., \& Tewksbury, D. (2007). Framing, agenda setting, and priming: The evolution of three media effects models. Journal of communication, 57(1), 9-20. https://doi. org/10.1111/j.0021-9916.2007.00326.x

[18] Halim, L., \& Meerah, T. S. M. (2016). Science education research and practice in Malaysia. In Science education research and practice in Asia (pp. 71-93). Springer, Singapore. https:// doi.org/10.1007/978-981-10-0847-4_5

[19] Madden, B. (2015). Pedagogical pathways for Indigenous education with/in teacher education. Teaching and Teacher Education, 51, 1-15. https://doi.org/10.1016/j.tate.2015.05.005

\section{$9 \quad$ Author}

Nor Farahwahidah Abdul Rahman is an expert in social science studies at the School of Education, Faculty of Social Sciences and Humanities, Uni-versiti Teknologi Malaysia (UTM), 81310 Skudai, Johor, Malaysia. She received her B.Sc (Physics education), Master of Philosophy (Physics Education) and PhD from Universiti Teknologi Malaysia. Her research interest is mainly on the social studies and equity for STEM education and education in general.

Article submitted 2021-09-10. Resubmitted 2021-10-19. Final acceptance 2021-10-22. Final version published as submitted by the authors. 